Canadian University Music Review

Revue de musique des universités canadiennes

\title{
Tros, Tevodas, and Haircuts: Ritual, Music, and Performance in Khmer Wedding Ceremonies
}

\section{Kathy M. McKinley}

Volume 19, numéro 2, 1999

Canadian Perspectives in Ethnomusicology

Perspectives canadiennes en ethnomusicologie

URI : https://id.erudit.org/iderudit/1014446ar

DOI : https://doi.org/10.7202/1014446ar

Aller au sommaire du numéro

Éditeur(s)

Canadian University Music Society / Société de musique des universités canadiennes

ISSN

0710-0353 (imprimé)

2291-2436 (numérique)

Découvrir la revue

Citer cet article

McKinley, K. M. (1999). Tros, Tevodas, and Haircuts: Ritual, Music, and Performance in Khmer Wedding Ceremonies. Canadian University Music Review / Revue de musique des universités canadiennes, 19(2), 47-60.

https://doi.org/10.7202/1014446ar

\section{Résumé de l'article}

This paper explores the importance of musical performance, its purpose and significance within Cambodian wedding ceremonies. While social and economic conditions of the early 1990s have contributed to the affordability of live wedding music in Phnom Penh, this paper suggests that the primary reason for the maintenance of live traditional wedding music is its role in enhancing the ritual and social efficacy of the ceremony, achieved through inspired and connected performances by singer-musicians as social-ritual actors.
All Rights Reserved (C Canadian University Music Society / Société de musique des universités canadiennes, 1999
Ce document est protégé par la loi sur le droit d'auteur. L'utilisation des services d'Érudit (y compris la reproduction) est assujettie à sa politique d'utilisation que vous pouvez consulter en ligne.

https://apropos.erudit.org/fr/usagers/politique-dutilisation/ 


\title{
TROS, TEVODAS, AND HAIRCUTS: RITUAL, MUSIC, AND PERFORMANCE IN KHMER WEDDING CEREMONIES
}

\author{
Kathy M. McKinley
}

Just before dawn, I am roused from sleep by soft sounds of early morning and the gentle stirrings of my neighbours as they prepare for the day: sweeping, shuffling feet, low voices, a radio playing softly, the faint hiss of frying food. Then, gradually, as the sky lightens, new layers of sounds expand my aural horizon and extend it into the city beyond my neighbourhood: bread vendors crying "numpan" as they walk through the streets, the steadily increasing hum of motorcycle traffic, the beeping of horns on the main streets. It is now 6 A.M. on a February morning in Phnom Penh, and, as I sit down to breakfast, I suddenly hear, in the distance, the voice of a popular Cambodian singer, blaring, distorted through loudspeakers. It is a recording of the song, "Caiw Priehm," played by a phleng kar somai (popular wedding music ensemble). Somewhere nearby, a household is preparing for a wedding. ${ }^{1}$

In her ethnography of Khmer village life in the early 1960s, "Svay, a Khmer Village in Cambodia," May Ebihara writes that " $[\mathrm{Khmer}]^{2}$ [w]eddings are the most joyous, delightful and (along with funerals) the most extravagant and elaborate of all life cycle ceremonies." 3 In the years following the publication of that dissertation, Cambodia entered perhaps the darkest period of its history, a period of prolonged violence and despair that has shattered the lives of its citizens and left the country's infrastructure and institutions in tatters: the genocidal horrors of the Khmer Rouge regime, a decade of Vietnamese occupation, years of civil war, hardship, loss, and poverty. Through at least some of that time, many traditional Khmer practices were banned, including life cycle rituals and traditional performing arts. The UN-supervised democratic elections of 1993 brought some hope of an end to the years of political and social unrest, and for some Khmer, new economic opportunities as thousands

1 Research for this project, conducted from late 1993 to early 1994, was generously funded by a fellowship from Fonds FCAR (Fonds pour la formation de chercheurs et l'aide à la recherche) and by the Association for Asian Studies. The epigraph is an excerpt from my fieldnotes describing a morning soundscape in February 1994, Phnom Penh. "Caiw Priehm," translated variably as "The Grandchild of Brahma," "Little Priehm," or "Chief/leader of the Brahman caste" (referring to the legendary male ancestor of the Khmer), is a standard wedding song used for the procession to the bride's family house.

2I am using the term "Khmer" rather than "Cambodian" to specify the traditional practices of Buddhist ethnic Khmer, and to differentiate these from traditions of other ethnic groups in Cambodia, and from the practices of non-Buddhist Cambodians (Christian or Muslim Cambodians, for example).

3 May Ebihara, "Svay, a Khmer Village in Cambodia" (Ph.D. diss., Columbia University, 1968), 474 
of peacekeepers arrived in the capital. Although fighting between government forces and the Khmer Rouge continued in several provinces after the elections, during my research (late 1993 to early 1994), Phnom Penh was relatively safe and peaceful. Khmer weddings in Phnom Penh, once again, were lavish, festive, and expensive, requiring days of preparation and straining the budgets of both families. Once again, the sounds of wedding music could be heard in the early morning hours on the streets of Phnom Penh. Although many Cambodians insist that the "proper" Khmer wedding ceremony should be (and was, several decades ago) a three-day event, today, most Khmer weddings in Phnom Penh are held on a single day, the ceremony proper in the morning, a photo session and visit to the temple in the afternoon, and, if the families are wealthy enough, a dinner-dance party in the evening.

From the time the ceremony begins, with the procession to the bride's house to its conclusion some five hours later, wedding musicians play almost continually. Pre-recorded phleng kar somai is used before the ceremony begins, broadcast at the bride's family house as participants busily prepare for the event, and it is this music that one often hears blaring from neighbourhood houses in the early morning. ${ }^{4}$ But once the wedding begins, the rituals of the ceremony must always be performed with live music. In other Khmer rituals and ceremonies, such as funerals, it is perfectly acceptable to use a prerecorded cassette instead of live musicians, but for any proper Khmer wedding, no matter how modest, live wedding music is not merely preferred, but considered essential.

In recent years, there has been an explosion of traditional Khmer weddings in Phnom Penh, with a corresponding increase in numbers of wedding musicians to perform at them. Socio-economic changes brought by the bubble of economic prosperity and political stability surrounding the UN-supervised democratic elections have encouraged more urban Cambodians to incur the tremendous financial costs the average Khmer wedding entails. ${ }^{5}$ The end of Cambodia's political isolation has also enabled parents with friends and relatives in Western countries to arrange marriages between Cambodian men in the United States, Canada, France, or Australia, and Cambodian women living in Phnom Penh.

Undoubtedly, social and economic conditions of the early 1990s have contributed to the affordability of live music at Khmer weddings in Phnom Penh. On average, phleng kar ensembles today account for a mere four percent of the total cost of the wedding, and there are a myriad of ensembles to choose from in the capital. However, the main reasons for maintaining live traditional music in the wedding ceremony lie not with budgeting concerns or even a

4 Phleng kar somai, known as "modernized" or "popularized" wedding music consists of the full traditional ensemble with added electric bass and drum set.

5 The average wedding I attended cost between $\$ 500$ and $\$ 2,000$ (US), many times greater than the average annual salary of a civil servant. Some of the expenses are offset by guests' financial donations (known as cong dai, and generally made at the end of the ceremony) but most Khmer families must either sell family assets or borrow money to pay for the weddings of their children. In the past, the groom's parents assumed responsibility for all costs of the wedding, but weddings today are usually financed equally by both sides. 
desire to maintain tradition, but instead, with the social and ritual role of singer-musicians within individual performances of wedding ceremonies.

Before discussing the specifics of music and musical performance in Khmer weddings, it will be helpful to consider, briefly, the scholarly contexts and theoretical implications of such an inquiry. At issue here is the general question of how music and musical performance becomes significant and meaningful in ritual contexts, or more precisely, how ethnomusicologists and anthropologists have chosen to interpret musical performance in ritual.

\section{PerspeCtives ON RITUAL AND MUSIC}

Although the importance of music and other performing arts is acknowledged in anthropological research on ritual, ${ }^{6}$ generally, it has fallen to ethnomusicologists to demonstrate exactly how and why musical performance is significant in ritual. ${ }^{7}$

Central to ethnomusicological explorations of ritual and music is a search for meanings communicated by musical performances within ritual or ceremonial contexts. Why is music necessary and meaningful in ritual? How is music effective within a ritual context? Musical sound, for instance, may enhance or transform an event from mundane to sacred, and ordinary to extraordinary. Deborah Wong and Rene T. A. Lysloff have demonstrated that in Thai music, musical sound has the power to create a "threshold to the sacred" to transport the listener to a different space..$^{8}$ Similarly, Jeff Titon demonstrates how song, as a form of sacred speech, may transform a Southern Baptist church into a "powerhouse for God" through its affective performance. ${ }^{9}$ With its ability to permeate physical barriers, music also can enlarge a ritual space, enabling people outside of visual range to participate aurally in the ritual.

Through song texts, ritual music also has the power to reference, to recall to the listener's mind another context ${ }^{10}$ and sometimes, to unite, create and/or

6See, for example, Bruce Kapferer, "Performance and the Structuring of Meaning and Experience," in The Anthropology of Experience, ed. Victor Turner and Edward M. Bruner (Urbana: University of Illinois Press, 1986): 188-206; Victor Turner, The Anthropology of Performance (New York: PAJ Publications, 1986).

7 Bruce Kapferer has described ritual as a "complex compositional form" that interweaves what we, for convenience, may call the genres of storytelling, music, dance, drama, liturgy, and the plastic arts (Kapferer, "Performance," 191). The implication in his definition is that a variety of media may be used throughout the ceremony to articulate its structure, to mark its progress and to impart a sense of directionality to the ceremony. Victor Turner emphasized ritual's rich textures and sensuality, describing ritual as "a symphony or synaesthetic ensemble of expressive cultural genres" (The Anthropology of Performance, 82). Turner revolutionized the study of ritual (and particularly life cycle rituals) with his dynamic, performance-oriented approach. Still, in Turner's work, music and other performative arts are largely ignored, or treated as epiphenomena-peripheral activities, meant to enhance other, more central and important actions within the ritual.

8Deborah Wong and Rene T. A. Lysloff, "Threshold to the Sacred: The Overture in Thai and Javanese Ritual Performance," Ethnomusicology 35, no. 3 (1991): 315-48.

9 Jeff Todd Titon, Powerhouse for God: Speech, Chant, and Song in an Appalachian Baptist Church (Austin, Texas: University of Texas Press, 1988).

10See Timothy Rice, May It Fill Your Soul: Experiencing Bulgarian Music (Chicago: University of Chicago Press, 1994); Steven Feld, Sound and Sentiment: Birds, Weeping, Poetics, and Song in Kaluli Expression, 2d ed. (Philadelphia: University of Pennsylvania Press, 1990); Titon, Powerhouse for God. 
reinforce communities (human, spiritual and natural) ${ }^{11}$. The significance and meaning of music in a ritual context may vary according to the context of the performance and the experience of the individual listener. As Rice observes:

Individual musicians and listeners operate within force fields created by the tug of politics, economics, aesthetics and tradition. Those forces determine neither musical practice, interpretations of musical meaning, nor emotional responses to music. Rather, individuals create, interpret, and give meaning to musical practice and its products as they weave music into "webs of significance" that join music in the fabric of everyday life. ${ }^{12}$

As Jeff Titon demonstrates, the meaning of orally performed texts is not self-evident from the text alone, but varies according to the context of the performance and the experience of the individual listener: "meaning is personal, local, referential, and memory based, rather than universal, open and plain." 13 In this analysis, the meaning of music in a ritual performance is, at times, fragmented and individualistic, yet rituals are also collective occasions, and musical performance may also enhance or create a sense of community among the participants of a ritual. Music "provides individuals with a feelingful way to experience themselves linked to others in social groups that share common practices and values." 14

Some ethnomusicological studies of ritual inquire into the "points of connection" between ritual and everyday life, ${ }^{15}$ focusing on ways in which musical performance actively maintains, creates, or dramatizes social distinctions, symbolizing, inverting, reinforcing, challenging or otherwise commenting upon social roles, norms, and values. ${ }^{16}$ Issues of power, gender, music, and value are at the forefront of many of these studies: musical performance is sometimes interpreted as an active agent in mediating conflict between the sexes, or as a vehicle for protest, change, or reversal of social norms. This approach is based upon the definition of ritual and ritual music not as primarily conservative or static reflections of social reality but as active social processes. The interpretive focus here is the society or group: the importance of musical performance, its purpose, significance, and the meanings of its various sym-

11 See Anthony Seeger, Why Suya Sing (Cambridge: Cambridge University Press, 1987); John Miller Chernoff, African Rhythm and African Sensibility: Aesthetics and Social Action in African Musical Idioms (Chicago: University of Chicago Press, 1979); Rice, May It Fill Your Soul.

12Rice, May It Fill Your Soul, 261.

13 Titon, Powerhouse for God, 213.

14Rice, May It Fill Your Soul, 302.

15 Kenneth George, "Music-Making, Ritual, and Gender in a Southeast Asian Hill Society," Ethnomusicology 37, no. 1 (1993): 12.

16Ellen B. Basso, "Musical Expression and Gender Identity in the Myth and Ritual of the Kalapalo of Central Brazil," in Women and Music in Cross-Cultural Perspective, ed. Ellen Koskoff (Urbana: University of Illinois Press, 1987), 163-76; Kenneth George, "Music-Making, Ritual, and Gender in a Southeast Asian Hill Society," 1-27; Marina Roseman, "Inversion and Conjunture: Male and Female Performance among the Temiar of Peninsular Malaysia," in Women and Music in Cross-Cultural Perspective, 131-50; Jane Sugarman, Engendering Song: Singing and Subjectivity at Prespa Albanian Weddings (Chicago: University of Chicago Press, 1997). 
bolic components are all interpreted in terms of ongoing negotiations of social relationships and group identities.

Although the Khmer wedding ceremony itself effects an important reordering of social relationships and identities, the significance or importance of phleng kar (the genre of music used in the wedding) is primarily its role in enhancing the ritual and social efficacy of the ceremony/event. In other words, musical performance in Khmer weddings is not essentially or necessarily a venue for social or political commentary. In my experience, musical performance becomes significant to participants of Khmer weddings partly through the structuring and referencing properties of musical sound, but also (and more importantly) through the musical, social, and ritual interaction between musician-singers and guests.

Before I proceed with a more detailed discussion of how this is accomplished, it will be useful to review some basic introductory information on ritual and musical practices in Khmer wedding ceremonies.

\section{PITHI RIEP Ka: The CEREMONY}

Most Khmer weddings in Phnom Penh today last about five hours and include thirteen to fifteen separate rituals. The ceremony officially begins with a rather elaborate procession: accompanied by musicians, the groom, his family, and friends march to the house of the bride's parents, carrying bride-price offerings-mostly fruits, traditional Khmer cakes, beverages - and important ritual objects to be used in the ceremony. Once the groom and his party reach the bride's house, they are met and greeted outside by the bride, and after an exchange of jasmine garlands, the bride and groom lead the rest of the processional party into the house. The main room of the house, where the wedding will take place, is usually decorated with tinsel and flashing Christmas lights (if available); colourful woven mats and/or carpets are laid on the floor for the guests to sit on. Outside, a large canopy is erected over a space adjoining the house to receive guests for meals and to accommodate those guests who cannot fit inside the house during the ceremony.

Once inside, the bride and groom greet their parents, bowing low three times to show their respect (twai bongkum) before presenting them with an offering of areca flowers ( $p k a$ sla). The bride and groom then retire to separate rooms to change clothing. In the meantime, several preliminary rituals of agreement between the two families take place: the ritual specialist (accar), who will lead the proceedings, introduces himself and formally requests permission to perform the ceremony (pithi peah aw phay); the offerings are arranged in long rows, counted, presented to, and accepted by the bride's parents (pithi roep phlae choe); and the parents of the bride and groom share a chew of betel nut signifying agreement to the match and to the proceedings about to take place (pithi pisa sla).

After an exchange of jewelry between the bride and groom, guests, musicians, photographers, and the accar all take breakfast (baba) outside. (The bride and groom must eat their meals in their respective rooms.) 
The main part of the ceremony occurs after breakfast, and includes at least eight separate rituals:

(1) a ritual haircut given to the bride and groom (pithi kat saq);

(2) washing of the groom's feet by the bride (pithi lieng coeng);

(3) presentation of areca flowers by the groom to parents/elder sibling (pithi cun kaiew pka sla);

(4) parting of the curtain to call the bride forth (pithi baek weignon);

(5) "opening of the tiep" (two small, footed, silver bowls with lids) (pithi baek tiep srei);

(6) invitation to various spiritual entities, including ancestral spirits (pithi saen/pren cidon cita);

(7) passing the popil (three, leaf-shaped, metal objects) around the bride and groom (pithi bongwoel popil);

(8) tying cotton threads around the wrists of the bride and groom (pithi cong dai).

Many of these rituals are long and complex, with multiple layers of meanings and significance. The four most important of these, according to several informants, are:

(1) kat saq, the ritual haircut given to the bride and groom, in order to "erase past misfortune," "bring good luck," and to physically mark the couple's transition to a new adult social status.

(2) bongwoel popil, a ritual in which three leaf-shaped metal objects (popil), each topped by a candle, are passed around the bride and groom several times. The popil, of Brahmanic origin, represents the female sex ("yoni") of Uma, Siva's wife; the candle attached to it is the male sex ("linga") of Siva. The union of the popil and candle in the ritual, the lighting of the candle, the action of waving the smoke from the candle towards the bridal couple, all act as powerful guarantees of fertility.

(3) saen/pren cidon cita, an invitation to spiritual entities, including, among others, the ancestral spirits, to partake in the ceremony, accept offerings prepared for them, witness the event and give their powerful blessings and protection to the new couple.

(4) cong dai, tying the wrists of the bride and groom with cotton threads, performed by the accar and all guests and family members present. This is a ritual of protection (the threads act as a ritual barrier to retain the vital essences of the bride and groom inside their bodies) and incorporation (bride and groom become reincorporated or "tied" into the fabric of the community by each member of the community itself).

\section{PhLeng Kar: The ENSEMble}

Phleng kar ensembles are so numerous in Phnom Penh today, that it is virtually impossible to stay in the capital during the dry season without hearing $\mathrm{Khmer}$ 
wedding music being performed in a procession or broadcast from a house, at least once. At the height of the wedding season, which coincides with Cambodia's dry season, from November to April or May, it is common to find wedding processions led by musicians every day of the week on almost every other street in Phnom Penh.

In February, the busiest month for weddings, there may be dozens of different groups of wedding musicians performing in the capital on a given day, yet none of these musicians are actually professional wedding musicians. There are no signs or storefronts advertising their services, and there is no one section of the city in which wedding musicians live or congregate. Weddings, being seasonal events in Cambodia, provide secondary employment to many Khmer men and women who, for various reasons, cannot support their families with one job. All wedding musicians I met held other careers; some were state-employed mohori musicians or music teachers using weddings to supplement meagre salaries, but many others were amateurs-farmers, civil servants, policemen-using their musical talents to earn extra cash. Ironically, the chronic poverty and economic uncertainty Cambodians have faced over the past nineteen years, since the end of the Khmer Rouge regime, have contributed to the maintenance of live phleng kar at urban Cambodian weddings, as the surplus of moonlighting wedding musicians has made them more accessible and their prices more competitive. One likely reason for the continuing presence of live music at weddings is its comparatively low cost-now only about four to six percent of the total expense of the wedding.

Today, the average phleng kar ensemble numbers about six persons. In addition to two singers, one male and one female, four male musicians play string and percussion instruments: ${ }^{17}$

(1) tro sao, a two-stringed fiddle with a cylindrical wooden resonator;

(2) takhe, a three-stringed fretted plucked zither;

(3) khim, a trapezoidal hammered dulcimer;

(4) skor, a goblet-shaped, single headed, hand drum.

According to my teachers, a full phleng kar ensemble should also include the tro $u$ (a lower pitched, two-stringed fiddle with a coconut shell resonator); ching (small brass hand cymbals, usually played by one of the singers); and an extra skor. Although it may be heard on recordings of traditional wedding music available in several city markets, the full ensemble is rarely used in Khmer weddings today. Competition from the multitude of wedding ensembles

17This ensemble is often referred to, by many musicians, as phleng karkondal, or "semi-traditional wedding music." The "true" wedding music ensemble, according to most Khmer I interviewed, is phleng kar boran, an older ensemble which was replaced by phleng kar kondal in Phnom Penh about forty to fifty years ago. Instruments of the older ensemble include: ksae diew (a plucked monochord); tro khmer ("Khmer tro," also known as tro ksae bei, or "three-stringed tro," a three-stringed spike-fiddle with a detached bow, similar to a Javanese rebab); capei dong weng (a plucked lute with three strings, a square body and long curved neck); pei a (a reed aerophone); two skor arak (hand drums); and ching (small brass hand cymbals). 
in Phnom Penh has encouraged musicians to streamline their ensembles to maximize profits.

Phleng kar music, like the music of other traditional Khmer ensembles such as pin peat, or mohori, is heterophonic in texture. ${ }^{18}$ Above a recurring rhythmic pattern on the drum, each musician plays or sings his/her own versions of the same melody, varying that melody on each repetition. The musicians converge on unisons and/or octaves at major structural points in the melody, marked rhythmically by open and closed strokes of the ching. Finding one's own style of playing in this way requires many years of diligent practice; a skilled musician is judged by his/her ability to continually alter the melodic line while remaining within the appropriate style of the ensemble. ${ }^{19}$

On average, musicians play between twenty and thirty different songs for a wedding: fourteen or fifteen within the rituals and at least five between rituals. For much of the ceremony, there is little creative choice in repertoire available for the musicians, as most of the rituals must be performed with one or more standard songs from the traditional phleng kar repertoire. Songs performed between rituals, however, may be taken from mohori (entertainment music) repertoire, or from older phleng kar songs belonging to rituals that have been eliminated from the ceremony.

On the day of the wedding, phleng kar musicians arrive at the house of the bride's parents before the wedding begins and play almost continually until the end of the ceremony, pausing only to share in the common breakfast ( $b a b a$ ) before the ritual haircut. Except during certain ritual events, musicians do not normally socialize with guests and family members, even during breaks, and for most of the ceremony they remain seated apart from the main circle of guests and family members, either just outside the front door or in a far corner of the main room.

\section{Significance and Meaning in PhLeng Kar Performance}

The importance of live music in a Khmer wedding may not be readily apparent to a casual observer. Khmer wedding music is supplied by a hired traditional band that, for much of the ceremony, remains separated from the core ritual action of the ceremony. Guests and main participants of the ceremony do not sing or dance, nor do they exercise an influence on the repertoire performed

18 Although Mantle Hood and David Morton have referred to the texture of Khmer music as "polyphonic stratification," I prefer Amy Catlin's term "functional heterophony," since the Khmer musician's intent is not to create a polyphonic texture, but to play one's own version of the same melody. See Mantle Hood, "Improvisation in the Stratified Ensembles of Southeast Asia," Selected Reports in Ethnomusicology 2, no. 2 (1975): 26; David Morton, "Instruments and Instrumental Functions in the Ensembles of Southeast Asia: A Cross-Cultural Comparison," Selected Reports in Ethnomusicology 2, no. 2 (1975): 7; Amy Catlin, "Apsaras and Other Goddesses in Khmer Music, Dance, and Ritual," in Apsara: The Feminine in Cambodian Art-An Exhibition and Publication on the Arts of Cambodian Women in the Los Angeles Area, ed. Amy Catlin (Los Angeles: The Woman's Building, 1987), 31.

19Sam-Ang Sam refers to this process as bamphley, although it does not appear to be a term universally applied or understood by all Khmer musicians; my own teachers, for example, spoke of "finding one's own way" (pliw). See Sam-Ang Sam, "The Pin-Peat Ensemble: Its History, Music and Context" (Ph.D. diss., Wesleyan University, 1988), 170. 
through direct requests. ${ }^{20}$ Why, then, do hosts, guests, and participants insist on live music, rather than using a cassette? Why do they value not only the musical sound of phleng kar, but the presence of a live band?

Within the event of a Khmer wedding, music, dance, drama, chant, and narratives performed throughout the rituals articulate the structure of the ceremony, marking its progress and imparting to it a sense of directionality. In a general sense, musical sound helps to define and delineate ritual space and time within the performance of a Khmer wedding. Khmer weddings are usually held at the house of the bride's parents. The ceremony itself takes place in a large room at the front of the house normally used for receiving guests (bantop totuel pnyiew) but it is rarely able to accommodate all of the wedding guests and many congregate outside at tables set up on one side of the house.

The ritual space of a Khmer wedding is really two spaces-the room "inside" and the space "outside"-both marked by special decoration and limited in size by the physical boundaries of the house and yard of the bride's parents. Key participants, close family members and honoured guests sit inside, while many of the "outsiders" (at this and other ceremonies and rituals) are colleagues, friends, and relatives of the bride and groom. Those seated outside at tables cannot, as a rule, see the rituals proceeding inside, but they are able to witness them aurally: the standard songs performed for each ritual of the wedding structure the progress of the ceremony, marking its stages and rituals, and enabling guests seated outside to follow, aurally, the progression of the wedding they cannot see. Music, performed throughout the wedding, broadcast through loudspeakers outside, and heard clearly by all guests and participants, unites the inside and outside spaces of the wedding into a single aural space. With its capacity to permeate space, musical sound creates, at Khmer weddings, a single social, communal, and ritual space, unifying groups of guests in separate physical spaces.

Musical sound, or more specifically, the ordered progression of wedding songs performed throughout the series of rituals of a Khmer wedding, helps to articulate the structure of the wedding ceremony as a whole, but songs performed within each ritual also mark both the form and progression of the individual ritual. A ritual typically begins with a speech by the accar in which he introduces and explains the ritual, and sometimes chants or gives a blessing. Following the accar's speech, the musicians begin the song for that particular ritual as the appropriate ritual action (for example, eating betel nut, washing feet, or cutting hair) is performed by the participants. Music, performed at the height of the ritual, during its enactment, marks that peak moment when the gestures are performed. With its own temporal logic, sense of flow, and structure, music also provides a special temporal framework for ritual gesture, creating a "time out of time," or, more precisely, a "pocket of time" within real time. ${ }^{21}$ Gestures performed within this special context, or "pocket," become

20For an example of this in weddings of central and northern India, see Gregory Booth, "Brass Bands: Tradition, Change, and the Mass Media in Indian Wedding Music," Ethnomusicology 34, no. 2 (1990): 245-62.

21 Wong and Lysloff, "Threshold to the Sacred," 316. 
charged with special significance; phleng kar music helps to define these actions as extra-ordinary, ritualized actions.

Seated on the periphery of the "inside," on the boundary between the two physical spaces of the wedding, musicians literally bridge the gap between inside and outside, between the core and peripheral areas of the ritual. For much of the ceremony, the musicians remain on this boundary, but in five key rituals, musical performance is brought to the foreground as musicians move from the periphery of the ritual space, the edges of the room, into the central core to become part of the main focus of the ritual action in ways that a pre-recorded musical performance could not approximate. ${ }^{22}$

One of these five, the ritual haircut (pithi kat saq), warrants closer attention because of the extensive and very visible participation of the singers, who perform most of the ritual. At an average of forty-five minutes in duration, the haircut is the longest ritual of the entire ceremony, and is perhaps the greatest test of a singer's talents, not only as a musician, but as dancer, actor, and comedian. The two standard songs for this ritual, "Sarikakaew" (Myna Bird) and "Trapeang Piei" (Pond Piei), are used for the act of cutting the hair, but this occurs only at the very end of the ritual. Most of the singers' performance is improvised dialogue and singing.

The ritual haircut begins with a blessing by the accar, who then calls upon two musicians to perform the remainder of the ritual. A male and female singer act out roles of tevoda and teptida, male and female heavenly beings depicted in human form, who are sympathetic to humans and assist them in times of need. The tevoda and teptida come to earth (than kondal, literally, "the middle level") from than loe (the "upper level"), bearing a pair of magical scissors made of gold and a silver comb, gifts from Indra (Sekhat Thevoriec). They are charged to cut the hair of the bride and groom with these scissors, thereby ensuring the future prosperity of the newlyweds. The tevoda and teptida change their appearance, transforming themselves into a beautiful human couple, and as they make the long journey to the house of the bride's parents, they sing, talk, joke, comment on their surroundings, and ask directions from unsuspecting humans. Once they find the right house, the tevoda and teptida convince the ritual specialist (accar) to allow them to give the bride and groom a haircut, and, because of the magical scissors they use, rings of gold and silver appear in the hair they cut. The bride's parents are duly impressed and purchase the scissors and comb from the tevoda and teptida, who then depart. At this point the tevoda/teptida become human again as they rejoin their fellow musicians outside of the ritual centre. Parents, family members and honoured guests then take turns cutting the bride's hair and groom's hair, and each time the scissors are used, rings of gold and silver are again discovered in the hair. ${ }^{23}$ Although in the past the bride and groom would have received real haircuts, often quite

22The rituals performed by singers include: hae (procession), pithi roep phlae choe (counting of the fruits), pithi kat saq (ritual haircut), pithi baek weignon (parting of the curtain), and pithi baek tiep srei (opening of the "tiep").

23 All of the cutting action, including that of the tevoda/teptida, is accompanied by two standard musical pieces, "Sarikakaew" and "Trapeang Piei." 
short, today no hair is actually cut: the comb is merely waved and the scissors are snipped around the head.

Most Khmer I interviewed consider the significance of the ritual haircut to be not merely a symbol of separation from the past or the physical mark of a new adult social role, but a powerful act of protection and purification. Ritual specialists I interviewed emphasized the prophylactic nature of this ritual: the act of cutting hair with special magical scissors guards against any misfortune and guarantees the future prosperity of the couple. Guests confirmed this interpretation, stating that the haircut is to "bring good luck."

The materialization of deities on earth, bearing sacred gifts and powerful objects (scissors, comb), gives the impression of a powerful ritual, and certainly the blessings and the protection the ritual provides are real enough to the participants. At the same time, the drama could hardly be called solemn: the main purpose of the singers' performance seems to be to make the guests and participants laugh, to create a shared, communal "good feeling." Rituals within the wedding ceremony may invoke and invite the divine, project mythological time into the present, and both recreate and reaffirm cosmological constructs, yet at the same time, rituals are performative, creative, variable, and sometimes intentionally humorous. In the kat saq ritual, the singers' performances are most successful if they are engaging and funny.

A large part of the performance of the haircut is comic drama, provided by the singers, and designed to ease tension, to draw in the guests, and to emphasize the communal bond between performers, guests, and participants. In this ritual, more than in any other, guests become directly focused on the singers, listening keenly to the dialogue and song texts. A crucial test of the success of the performance is the extent to which the singers are able to include the guests in the drama, to draw them in, and to involve them in the humour. To this extent, the comic drama within the kat saq is a point within the wedding where musical and dramatic performance becomes a means of creating and reinforcing a sense of community among the two families of the wedding.

Singers must rely upon a variety of talents to produce a good performance: they must demonstrate acting ability and some dancing skills in addition to musical talents. But since the guests, for the most part, are listening to the words being sung and/or spoken, verbal skills are of primary importance. To engage their hosts and the guests of the ceremony, singers endeavour to find topics and jokes for conversation and improvised singing (ayai) which would be amusing, interesting, and pleasing to the guests and hosts. Part of the humour is achieved through playing with the sacredness implied by the drama: tevodas have descended from the heavens on a sacred mission, but walk around in human form, speak in ordinary Khmer (not the polite-style, superior forms of address used for royalty and monks) about ordinary, earthly things. Disguised as humans, the tevoda/teptida may flirt with each other, or, more hilariously, with guests or participants (such as the accar, or the attendants). Teasing the bride and groom and their attendants, who attempt to maintain their composure, is invariably part of the performance, and often draws the most laughter from the guests. Indeed, in most performances I witnessed, much of the humour was 
achieved through interaction between tevoda/teptida and "human" guests and participants.

The long drama within the ritual haircut normally comprises several distinct sections of dialogue alternating with song and/or ayai style performance, depending on the singers' skill, knowledge, and background. Ayai, a kind of verbal jousting in which male and female singers alternate solo singing with instrumental interludes, is the most common form of musical interaction used within this drama. The best ayai singing occurs when the two singers have worked together before and are experienced with the form, but this is not always the case. In one wedding I attended, the female singer was hired only for the haircutting ritual and, in fact, was booked to perform at another wedding later in the same morning. The two singers did not know each other at all, were testy and competitive, and rushed through the performance. Guests quickly lost interest in the performance and wandered outside. Until the end of the ritual, when family members took turns cutting the hair of the bride and groom, the room was virtually empty.

Many other singers whose performances were more successful tailored their presentation to suit the tastes of their hosts. A singer might, for example, single out honoured guests (a government official, or an esteemed elderly relative, for instance), either by interacting with them directly and respectfully, or by making references to them or their work in the drama. At one wedding in which the minister of culture was in attendance, the male singer (as tevoda) remarked on the recent and welcomed renaissance of Khmer traditional culture. Other singers at a wedding in which a family member was particularly fond of mohori music, used modified mohori songs in their performance instead of ayai. My own presence at weddings often became a means of creating humour as well, and in fact, most singers found it impossible to resist the opportunity to use me to their advantage when constructing their comic performances. For example, singers (as tevoda/teptida) would appear shocked at seeing a barang (Westerner), convinced they had "taken a wrong turn" and were no longer in Cambodia.

References to current events and life in Phnom Penh are sometimes used in kat saq performances as a source of humour. In one performance, a singer "mistook" the accar, dressed in a long, lacy, open jacket, as an UNTAC official (United Nations Transitional Authority in Cambodia). On another occasion, a singer made a humorous reference to the "bountiful" Tuol Kork, a red-light district of Phnom Penh. In a sense, the drama within the kat saq creates an opportunity for humorous self-reflection, an occasion for Khmer to step outside of their everyday concerns to laugh at themselves and/or aspects of their contemporary culture and lives. As heavenly beings, accustomed to viewing human life from above, the tevoda and teptida have a unique, external perspective on everyday life in Cambodia which allows them to make rather pointed comments on current political or social issues. However, in my experience, the ritual haircut is neither a venue for political and social commentary, nor is it essentially self-reflexive. Rather, the structure of the drama provides an opportunity for self-reflective commentary that may or may not occur in a given 
performance. As guests and participants repeatedly informed me, the singers' main goal is to make everyone laugh; self-reflective commentary is but one of a variety of ways in which they may do this.

Within the performance of the ritual haircut, guests expect to be entertained, and indeed, the ritual haircut is the only ritual in the wedding ceremony in which the intent of the performance is comedy. The singers' performance allows the guests to relax and enjoy themselves; it provides important comic relief within the long series of rituals of the five-hour ceremony. Although guests will usually single out the wrist-tying ritual, or the fêting of the ancestral spirits as the most important rituals of the ceremony, the social consequences of the ritual haircut are probably the greatest of all the rituals within the wedding ceremony.

Much depends on this performance. For the singers, this ritual is their greatest opportunity to "shine," to demonstrate their talents, their creativity, and to build their reputations. A good performance will likely result in more performing opportunities in the future and could also persuade the hosts of this wedding to make an additional payment to the singers.

The hosts also have much to gain from a good kat saq performance. At the end of the wedding, guests are usually expected to make a financial contribution (cong dai) to the bride and groom, to help offset the enormous cost of the wedding. If guests are pleased and well entertained by the musicians, they will likely give generously. However, as one musician informed me, if the performance is poor, "the guests will feel cheated," and may leave without contributing much at all.

According to some guests, the kat saq ritual is also an important opportunity for the bride and groom to feel comfortable with each other. Even today, many Khmer weddings are arranged marriages, and I attended several in which the bride and groom met for the first time on their wedding day. By teasing them gently during this performance, the singers attempt to diffuse any tension between the bride and groom, helping the new couple to relax, perhaps even to start their married life together on the right track. ${ }^{24}$

\section{CONCLUSIONS}

In Cambodian wedding ceremonies, musical sound and song texts help to define and delineate ritual space and time. The sound of phleng kar unifies the disparate physical spaces of the ceremony, creating a single aural/ritual space, and both sound and text mark the stages of the ceremony. To some extent, this may explain why phleng kar is valued by Cambodians in their wedding ceremonies, but it does not explain the importance of live music. Within the performance of a wedding, the actions and choices of individual musicians

\footnotetext{
24Because singers, more than instrumentalists, are the most visible musical performers in a Khmer wedding, it is not surprising that they usually receive a greater portion of the payment made to the group (this is especially true of male singers), and that they are recognized more than the instrumentalists as individuals. Male singers are also often capable of playing most of the instruments in the ensemble, but their talents as singers, actors, dancers, and comedians-particularly well demonstrated in the performance of the ritual haircut-can make them quite famous.
} 
create opportunities within the ceremony for humour, for self-reflection, and (particularly through interaction of guests, participants, and musicians) for reinforcing or creating a sense of community among the two families present. Such valued opportunities and outcomes depend on having live musicians on site and could not be realized through pre-recorded music.

The performative, variable, and creative qualities of ritual are most evident in the ritual haircut, in which the singers must vary their performance to suit the tastes of their hosts and guests. Singers must reach out to the guests and involve them and so must be creative in each performance to achieve the desired result: a funny, engaging performance that involves the wedding guests, creates a good feeling shared among all, and heightens a sense of community among all present. Because of its popularity, the social consequences of this ritual performance are possibly the greatest of any ritual in the ceremony.

It is significant that, although the wedding ceremony has been abbreviated over many decades, the singers have seen an expansion of their role as active participants in the ceremony. In the context of a Khmer wedding, individual creativity does make a difference, and in the ritual haircut the ingenuity and skill of individual singers may well influence the overall success of the entire ceremony. It seems, ultimately, that significance and value of ritual music in this context stems from inspired and connected performances by singer-musicians as social-ritual actors.

\section{Abstract}

This paper explores the importance of musical performance, its purpose and significance within Cambodian wedding ceremonies. While social and economic conditions of the early 1990s have contributed to the affordability of live wedding music in Phnom Penh, this paper suggests that the primary reason for the maintenance of live traditional wedding music is its role in enhancing the ritual and social efficacy of the ceremony, achieved through inspired and connected performances by singer-musicians as social-ritual actors. 